\section{Infections in cirrhotic patients}

Ahmed El Shabrawi, Mohammed Abdelaziz, Nasser Mousa
MJVH

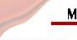

\begin{abstract}
Summary
Cirrhosis is considered to be the final stage of various liver injuries. Cirrhotic patients are more vulnerable to an increased incidence of infections than normal population. Various theories had been postulated to explain the higher frequency of infections among cirrhotic patients including alterations in the enteric flora, dysfunction of the intestinal barrier and impairment of the host defense mechanisms. In particular, bacterial infections could be a precipitating factor for deterioration of the liver condition and occurrence of number of life threatening complications such as acute on top of chronic liver failure (ACLF), acute kidney injury, hepatic encephalopathy, coagulation defect and variceal bleeding. Among the infections described in cirrhotic patients, spontaneous bacterial peritonitis, pneumonia, urinary tract infection, soft tissue infection, and bacteraemia were found to be the most repeatedly encountered. Assuming that, infections in cirrhotic patients are considered as alarming signs, prompt and definitive management strategies should be undertaken. This manuscript focuses on bacterial infections in cirrhotic patients as regard pathophysiology, types, consequences and management.
\end{abstract}

Keywords: Cirrhosis, Infection, Spontaneous bacterial peritonitis and acute on top of chronic liver failure

\section{Medical Journal of Viral Hepatitis \\ (MJVH) 2019; 4 (1) - pp. 5-14}

Received: 22/8/2019

Revised: 21/10/2019

Accepted: 25/10/2019

Published Online: 15/11/2019

(Ahmed El Shabrawi, Mohammed Abdelaziz,

Nasser Mousa) tropical Medicine dept.

Faculty of Medicine, Mansoura Univ., Egypt

* CA: Ahmed El Shabrawi

drahmedyaser23@gmail.com

\section{Introduction}

Cirrhosis is the end stage of a chronic liver disease lead to a syndrome called cirrhosisassociated immune dysfunction syndrome (CAIDS $)^{1}$. The resultant development of CA IDS disables the habitual efficient protection against different infections ${ }^{2-4}$. Cirrhotic patients have an increased incidence of infections that are a chief cause of morbidity and mortality. In addition to alterations in the enteric flora and the intestinal barrier due to portal hypertension, susceptibility to infection can be documented to an impairment of the defense mechanisms against infections ${ }^{5-7}$. A number of dysfunctions of the reticulo-endothelial system, neutrophil granulocyte functions, humoral and cell-mediated immunity have been described in patients with cirrhosis ${ }^{8}$. Furthermore, those living with cirrhosis can report a high predisposition to sepsis and septic shock, due to the excessive response of pro-inflammatory cytokines and hemod- ynamic derangement'. Spontaneous bacterial peritonitis, pneumonia, urinary tract infection, soft tissue infection, and bacteremia are the most common infection described in cirrhotic $^{5,10,11}$.

\section{Cirrhosis and Immunity}

The physiological abilities to know antigens and activation of the immune response are mutually linked and coordinated so that the immune response to the pathogen can be as efficient and quick as possible. In the case of cirrhosis, there are some irregularities of the immunological response. They can change dynamically at different stages of the illness (balanced cirrhosis, decompensated cirrhosis, and acute cirrhosis) and they are also dependent on the organ damage and stimulating factors, e.g. bacterial translocation. In the development of CAIDS, the tolerance of monocytes towards 
endotoxins and bacterial antigens plays a significant role. The tolerance develops as a result of the low density of the above-mentioned factors as well as their penetration through the damaged intestinal barrier ${ }^{12}$. The liver acts as a bacterial filter. Its phagocytic system reticuloendothelial system (RES) plays an important role in the elimination of intestinal bacteria and endotoxins ${ }^{13}$. In cirrhotic patients, the essential functions of RES are weakened and the number and the efficiency of stellar cells (Kupffer cells, hepatic macrophages) are decreeasing $^{\mathbf{1 4 , 1 5}}$. Moreover, in cirrhosis there is disturbed synthesis of proteins responsible for the innate immune resistance and reduction of the secretion of receptors responsible for antigen recognition, all of which decreases the antibacterial action of cytophages. These conditions are mostly visible in the case of advanced cirrhosis and ascites (characterized by small levels of complements C3, C4, C50 in the serum and effusion fluid) and they tend to result in increased susceptibility to various bacterial infections ${ }^{16,17}$. The crucial role of these irregularities is played by genetic polymerphisms of receptors responsible for the pattern recognitions of toll like receptors (TLR) and nucleotide-binding oligomerization domain 2 (NOD2). As a result, these receptors are less professional in binding polysaccharides and/or bacterial endotoxins, which expose the affected patients to coinciding and/or ensuing infections $^{18}$.

\section{Pathogenesis of Bacterial Infections}

Many factors interacting in producing bacterial infections in cirrhosis including, gut microbiota, intestinal permeability, bacterial translocation (BT) and immune deficiency which may be acquired or conferred by genetic susceptibility $^{19}$

\section{Gut microbiota}

An essential tip to prevent pathological BT is to maintain gut bacteria under very tight control. On the other hand, intestinal bacteria contribute to symbiosis by educating and maintaining the host immune system. Disproportion of this fine homeostasis between host and microbiome can direct to disease $\mathrm{20-22}^{\mathbf{2 0}}$. Alteration in the microbiome occurs as quantitative intestinal bacterial overgrowth (IBO) or qualitative (dysbiosis) changes. IBO is a common feature in cirrhotic patients and occurs mostly in the small intestine ${ }^{23-25}$. IBO is multifactorial, and causative factors include modulation of gastric acid secretion, decline in intestinal motility, lack of bile constituents and antimicrobial peptides in addition to portal hypertension ${ }^{\text {26-31 }}$. Patients with cirrhosis and IBO more frequently have SBP compared to patients without bacterial over growth ${ }^{31}$. Experimental IBO itself can result in microbial translocation and liver inflammation $^{32}$, documinting the importance of quantitative microbiome changes. Moreover, deceasing the intestinal bacterial burden with antibiotics ameliorates experimental liver disease $\mathrm{33,34}^{3}$ and, decreases the liver disease severity ${ }^{35,36}$ and infectious complications in patients with advanced cirrhosis.

\section{Intestinal barrier dysfunction}

Increased intestinal permeability has been established by different methods and shown to be mostly found in advanced stages of disease and septic complications. Tight junctions (TJ) between epithelial cells limit paracellular permeation and thus translocation of bacterial products. Changes in TJ proteins are present in cirrhosis and most possible loosen TJ-function $^{37,38}$. Transcytosis appears to represent the major route but is poorly defined in cirrhosis. One of the key regulators modulating TJ and transcytosis is tumor necrosis factor- $\alpha$, which is increased in the gut-associated lymphatic tissue in advanced cirrhosis ${ }^{\mathbf{3 9 4 0}}$. Many mediators that can limit the direct contact of intestinal bacteria to the epithelial surface such as $\operatorname{IgA}^{41}$, biliary lipids ${ }^{42}$, and antimicrobial peptides are deficient in cirrhotic patients $^{30}$. Also, in cirrhotic patients there is deficiency in expression of the antimicrobial protein $\operatorname{Reg} 3 \mathrm{~g}$, which maintains a physical barrier between the epithelial cell surface and intestinal microbes ${ }^{43}$.

\section{Consequences of Bacterial Infections}

Bacterial infection is a most important cause of acute decompensation of cirrhosis even associated with failure in other organs and high risk of short-term death ${ }^{44-47}$. These patients are considered to have acute-onchronic liver failure ${ }^{46}$. A large prospective 
observational study (CANONIC study) used the CLIF-Sequential Organ Failure Assessment (SOFA) score to recognize organ failures classified a ACLF into three ACLF grades, with increasing risk of short-term death from grade $1(22 \%)$ to grade 3 $(77 \%)^{48}$. Bacterial infection was the most common precipitating event of ACLF $(33 \%)^{48}$ and, ACLF was more recurrent in patients with SBP or pneumonia than in those with infections at other sites ${ }^{48,49}$.

\section{Infection and liver Damage}

The liver damage as a consequence of infection depends on both, the intensity of the inflammatory response and the intrinsic capacity of the liver to tolerate the effects of the inflammatory response. This tolerance depends on inducible mechanisms such as anti-apoptotic pathways ${ }^{50}$. In the situation of Gram-negative infections, normal liver is protected against LPS-induced, TNF-alpa that is mediated apoptosis because of synchronized induction of nuclear factor- $\mathrm{j} B$ (NF-jB)-dependent anti-apoptotic molecules ${ }^{51}$. However, cirrhotic liveris abnormally susceptible to LPS-induced, TNF-a-mediated apoptosis since NF-jB-target anti-apoptotic molecules cannot be correctly induced ${ }^{51}$. Thus, in cirrhotic patient, infection-produced liver failure may be related to both, an extreme pro-inflammatory response and reduction in the hepatic capacity of tolerance.

\section{Kidney Failure}

Bacterial infections ${ }^{52,53}$ are well-established triggers of kidney failure in cirrhotic patient. Patients with SBP lacking shock who shows the highest pro-inflammatory response are those who are at risk of developing kidney failure $^{52}$. significantly, in these patients, kidney failure frequently develops while resolution of infection has been obtained by antibiotic therapy ${ }^{53}$ signifying that, organ failure does not result from intrinsic virulence (i.e., tissue damage directly caused by bacteria) but rather extrinsic virulence (i.e., produced by the excessive inflammatory response of the host) or sepsis-related alterations in hemodynamics ${ }^{53}$. A potential role for alterations of tolerance mechanisms in the development of kidney failure ${ }^{54}$ has not yet been investigated.

\section{Brain Failure}

Bacterial infections are recurrent precipitating factor of hepatic encephalopathy ${ }^{55}$. Data reveal that, infections may produce brain oedema in cirrhotic patient. It is currently uncertain whether this water accumulation is predominantly intracellular or extracellular. There is some evidence that both mechanisms combine to cause brain edema and hepatic encephalopathy $(\mathrm{HE})^{56}$.

\section{Coagulation Failure}

Infection in cirrhotic patients specially if associated with ACLF is connected with, disseminated intravascular coagulation (DIC), which can be activated by pro-inflammatory cytokines compared to patients free from $\mathrm{ACLF}^{47}$. Thrombi in the microvasculature of a vital organ may engage in tissue hypoxia ${ }^{50}$. Important, activation of coagulation may stimulate inflammation ${ }^{50}$.

\section{Variceal Bleeding}

Bleeding from esophageal varies is a welldocumented risk factor for bacterial infection in patients with cirrhosis ${ }^{57}$. Furthermore, it has been proposed that conversely bacterial infection might increase the risk of variceal hemorrhage ${ }^{58}$.

\section{Adrenal Insufficiency}

Patients with cirrhosis and septic shock may have high incidence of relative adrenal insufficiency $(\mathrm{RAI})^{59}$. This RAI seems to be linked with poor liver function, kidney failure, refractory shock and hospital mor-tality ${ }^{60}$. RAI could result in decreased corticosteroidrelated anti-inflammatory mechanisms and as a result unrestricted infection creates proinflammatory molecules. In addition, under stress conditions, defective corticosteroid production could be associated with decreased capacity of tolerance of vital organs ${ }^{50,61}$. Serum total cortisol overestimates the prevalence of RAI in cirrhosis due to low transcortin and albumin concentrations so that, free cortisol levels have been optional method for the diagnosis of ${ }^{62,63}$. Also, the 
value of delta total cortisol as a diagnostic marker of RAI not affected by changes in transcortin or albuminlevels ${ }^{64}$.

\section{Spontaneous Bacterial Peritonitis}

Spontaneous bacterial peritonitis (SBP) is a bacterial infection of previously sterile ascitic fluid in the absence of other intra-abdominal source of infection. The development of SBP may occur in patients with ascites regardless of its etiology ${ }^{65}$. SBP present in $10-30 \%$ of hospitalized patients with cirrhosis and ascites $^{65}$. It is one of the major bacterial infections in this group of patients ${ }^{66}$ and is associated with a severe prognosis ${ }^{67}$. The 30-day mortality rate is estimated at $26-48.7 \%^{68-70}$. SBP, accounting for $22.5 \%$ of infectious etiology of acute on chronic liver failure ${ }^{71}$. After the SBP episode, the 1-year survival rate is estimated at $30 \%$ to $50 \%$ and 5 -year survival at $15.2 \% \%^{72,73}$. The hepatorenal syndrome occurs in 33\% of patients with SBP and is the strongest predictor of in-hospital mortality in this patients ${ }^{74}$. Infection may be manifested as the systemic inflammatory response syndrome (SIRS), sepsis, multiple organ failure, acute on chronic liver failure and death ${ }^{75}$. gram-positive bacteria were responsible for about $1 / 4$ episodes of $\mathrm{SBP}^{76,77}$. However, with increasing frequency of hospitalization, the use of invasive procedures, increased exposure to broad-spectrum antibiotics, the widespread antibiotic prophylaxis with fluoroquinolones and change in the profile of pathogens causing spontaneous bacterial peritonitis. Now, multi-drug resistant pathogens resistant to antibiotics from 3 or more groups, including $\beta$-lactams - are increasingly isolated ${ }^{69}$. SBP was divided into nosocomial (hospital acquired), health-care associated (HCA) and community acquired (CA). This division commonly reflects antibiotic resistance of the pathogens. Due to variation of SBP producing organism, the first-line empirical antibiotic therapy should be chosen according to the local epidemiology ${ }^{78}$. Characteristics of SBPinducing pathogens vary depending on where the infection was acquired. In hospital-acquired infections, multi-drug resistant pathogens are more often cultivated, which in turn contributes to less effective treatment and worse prognosis $^{70,79}$. The diagnosis of SBP is based on diagnostic paracentesis the greatest sensitivity for the diagnosis of SBP is reached with a cut-off neutrophil count of $250 / \mathrm{mm}^{3}$, although the greatest specificity is reached with a cut-off of 500 neutrophils $/ \mathrm{mm}^{3}{ }^{80-83}$. Ascites culture is essential to guide antibiotic therapy. Patients with an ascitic fluid neutrophil count $\geq 250$ cells $/ \mathrm{mm}^{3}$ and negative culture have culture-negative SBP. Some patients have 'bacterascites' in which cultures are positive but there is normal ascitic neutrophil count $\left(<250 / \mathrm{mm}^{3}\right)^{80}$. Spontaneous fungal peritonitis is sporadic, less known, but observational records suggest a poorer prognosis $^{84}$. According to EASL clinical guidelines in management of patients with decompensated cirrhosis concerning management of SBP, the option of antibiotic treatment should be depended on the knowledge of origin of the infection, the presence of individual risk for multi drug resistant bacteria and the local microbiology. Thirdgeneration cephalosporins are recommended as first-line antibiotic treatment for community-acquired SBP in countries with low rates of bacterial resistance. In countries with high rates of bacterial resistance piperacillin/tazobactam or carbapenem should be considered. The effectiveness of antibiotic therapy should be checked with a second paracentesis at 48 hours from starting treatment. Failure of first-line antibiotic therapy should be expected if there is worsening of clinical signs and symptoms and/or increase or no obvious reduction in leucocyte count (at least 25\%) in $48 \mathrm{~h}$. The duration of treatment should be at least 5-7 days. Patients with SBP have an increased incidence of hepatorenal syndrome, which may be associated with reduction of the effective volume of blood supply to the kidneys as consequence to infection. Consequently, in addition to antibiotic therapy in the treatment of SBP, intravenous infusions of albumin in a dose of $1.5 \mathrm{~g} / \mathrm{kg}$ on the day of diagnosis and $1 \mathrm{~g} / \mathrm{kg}$ on the third day should be used ${ }^{85}$. Because most attacks of SBP are believed to result from the translocation of enteric gram-negative bacteria, the ideal prophylactic agent should be safe, affordable and effective at decreasing the amounts of 
these organisms from the gut while preserving the protective anaerobic flora. These prophylactic antibiotics must be firmly restricted to patients at high risk of $\mathrm{SBP}^{86}$. Three high-risk patient populations have been identified: i) patients with acute GI haemorrhage; ii) patients with low total protein content in ascitic fluid and no prior history of SBP (primary prophylaxis) and iii) patients with a previous history of SBP (secondary prophylaxis) ${ }^{87}$. Primary prophylaxsis with norfloxacin $(400 \mathrm{mg} /$ day $)$ in patients with Child-Pugh score $\geq 9$ and serum bilirubin level $\geq 3 \mathrm{mg} / \mathrm{dl}$, with either impaired renal function or hyponatraemia, and ascitic fluid protein lower than $15 \mathrm{~g} / \mathrm{L}$ is recommended.

\section{Infections Other Than SBP}

Throughout hospitalization about 25-30\% of cirrhotic patients have non-SBP infections frequently, urinary tract, pneumonia, skin and soft tissue infections, and bacteraemia ${ }^{88,89}$. Nearly, $60 \%$ of non-SBP infections were health care associated or nosocomial of origin. In this population, the highest risk for 30-day mortality was related to age, hepatic encephalopathy, serum sodium, and albumin levels ${ }^{\mathbf{8 9}, 90}$. In particular, non-SBP infections, in addition to SBP, are known as frequent precipitating factors for $\mathrm{ACLF}^{91}$. The initial presentation of many bacterial infection may be subtle and not very specific, so that, the clinical suspicion is vital. Indeed, all cirrhotic patients should be considered as potentially infected until proven otherwise ${ }^{92}$. To optimize the empirical antibiotic treatment, it is reasonably important to differentiate between community acquired, health care associated and nosocomial infections. Mortality for nosocomial infections is higher (25-48\%) compared to community- acquired infection (7-21\%) since they are more commonly sustained by MDR bacteria ${ }^{92-94}$. Similar to that in SBP, there is a growing challenge of resistant bacteria among non-SBP infections. Among patients with cirrhosis and blood stream infections gram-negative bacteria, gram-positive bacteria and candida were the cause of blood stream infections episodes in $53 \%, 47 \%$ and $7 \%$ respectively ${ }^{95}$.

\section{Conclusions}

Bacterial infection is universal in cirrhotic patients and accounts for major morbidity and mortality in these groups of patients. Cirrhotic patients are immunocompromised one with high susceptibility to develop spon-taneous bacterial infections, hospital-acquired infections, urinary tract infection and a variety of other infections.

\section{Reference}

1- Bonnel A, Bunchorntavakul C, Reddy K. Immune dysfunction and infections in patients with cirrhosis. ClinGastroenterol Hepatol 2011; 9 (9): 727-738.

2-Jalan R, Fernandez J, Wiest R, Schnabl $\mathrm{B}$, Moreau R, Angeli P, et al. Bacterial infections in cirrhosis: A position statement based on the EASL Special Conference 2013. J. Hepatol 2014. 60 (6): 1310-1324.

3-Keeffe $E$, Iwarson $S$, McMahon $B$, Lindsay K, Koff R, Manns M, et al. Safety and immunogenicity of hepatitis A vaccine in patients with chronic liver disease. Hepatology. 1998; 27 (3): 881-886.

4-Keeffe E, Krause D. Hepatitis B. V|accination of patients with chronic liver disease. Liver Transpl Surg. 1998; 4 (5): 437-439.

5-Rimola A, Navasa M. Infections in liver disease. In: McIntyre N, Benhamou J, Bircher J, et al, (eds.) Oxford Textbook of Clinical Hepatology, $2^{\text {nd }}$ ed., Oxford University Press, Oxford. 1999; 1861-1866.

6-Morencos F, de lasHeras-Castaño G, MartinRamos L, López M, Ledesma F, Pons F. Small bowel bacterial overgrowth in patients with alcoholic cirrhosis. Dig Dis Sci. 1995; 40 (6): 1252-1256.

7-Garcia-Tsao G, Lee F, Barden G, Cartun $\mathrm{R}$, West A. Bacterial translocation to mesenteric lymph nodes is increased in cirrhotic rats with ascites. Gastroenterology. 1995; 108 (6): 1835-1841.

8-Sipeki N, Antal-Szalmas P, Lakatos P, Papp M. Immune dysfunction in cirrhosis. World J. Gastroenterol. 2014; 20 (10): 2564-2577.

9-IwakiriY, Shah V, Rockey D. Vascular pathobiology in chronic liver disease and cirrhosis - Current status and future directions. J. Hepatol. 2014; 61 (4): 912-924 
10-Ascione $\mathrm{T}$, Pagliano $\mathrm{P}$, Balato $\mathrm{G}$, Mariconda M, Rotondo R, Esposito S. Oral therapy, microbiological findings, and comorbidity influence the outcome of prosthetic joint infections undergoing 2-stage exchange. J. Arthroplasty. 2017; 32 (7): 2239-2243.

11- Ascione T, Pagliano P, Mariconda M, et al. Factors related to outcome of early and delayed prosthetic joint infections. J. Infect. 2015; 70 (1): 30-36.

12-Biswas S, Lopez-Collazo E. Endotoxin tolerance: new mechanisms, molecules and clinical significance. Trends Immunol. 2009; 30 (10): 475-487.

13-Gao B, Jeong W, Tian Z. Liver: an organ with predominant innate immunity. Hepatology. 2008; 47(2): 729-736.

14- Rimola A, Soto R, Bory F, Arroyo V, Piera C, Rodes J. Reticuloendothelial system phagocytic activity in cirrhosis and its relation to bacterial infections and prognosis. Hepatology. 1984; 4 (1): 5358.

15-Manifold I, Triger D, Underwood J. Kupffer-cell depletion in chronic liver disease: implications for hepatic carcinogenesis. Lancet. 1983; 2 (8347): 431433.

16- Runyon B, Morrissey R, Hoefs J, Wyle F. Opsonic activity of human ascitic fluid: A potentially important protective mechanism against spontaneous bacterial peritonitis. Hepatology. 1985; 5 (4): 634637.

17- Runyon B. Patients with deficient ascitic fluid opsonic activity are predisposed to spontaneous bacterial peritonitis. Hepatology. 1988; 8 (3): 632-635.

18- Guarner-Argente C, Sánchez E, Vidal S, Román E, Concepción M, Poca M, et al. Toll-like receptor 4 D299G polymorphism and the incidence of infections in cirrhotic patients. Aliment Pharmacol Ther. 2010; 31 (11): 1192-1199.

19-Berg R, Garlington A. Translocation of certain indigenous bacteria from the gastrointestinal tract to the mesenteric lymph nodes and other organs in agnotobiotic mouse model. Infect Immun. 1979; 23 (2): 403-411.
20- Fernandez J, Navasa $M$, Gomez J, ColmeneroJ, Vila J, Arroyo V, et al. Bacterial infections in cirrhosis: Epidemiological changes with invasive procedures and norfloxacin prophylaxis. Hepatology. 2002; 35 (1): 140-148.

21- Hooper L, Littman D, Macpherson A. Interactions between the micro- biota and the immune system. Science. 2012; 336: 1268-1273.

22-Littman D, Pamer E. Role of the commensal microbiota in normal and pathogenic host immune responses. Cell Host Microbe. 2011; 10 (4): 311 323.

23- Bauer T, Steinbruckner B, Brinkmann F, Ditzen A, Schwacha H, Aponte J, et al. Small intestinal bacterial overgrowth in patients with cirrhosis: prevalence and relation with spontaneous bacterial peritonitis. Am J. Gastroenterol. 2001; 96 (10): 2962-2967.

24- Morencos F, lasHeras C, Martin R, Lopez Arias M, Ledesma F, Pons R. Small bowel bacterial overgrowth in patients with alcoholic cirrhosis. DigDis Sci. 1995; 40 (6): 1252-1256.

25- Pande C, Kumar A, Sarin S. Smallintestinal bacterial overgrowth in cirrhosis is related to the severity of liver disease. Aliment Pharmacol Ther. 2009; 29 (12): 1273-1281.

26- Chang $C$, Chen $G$, Lien $H$, Yeh $H$. Small intestine dysmotility and bacterial overgrowth in cirrhotic patients with spontaneous bacterial peritonitis. Hepatology. 1998; 28 (5): 1187-1190.

27-Inagaki T, Moschetta A, Lee Y, Peng L, Zhao G, Downes M,et al. Regulation of antibacterial defense in the small intestine by the nuclear bile acid receptor. Proc Natl Acad Sci U S A. 2006; 103 (10): 3920-3925.

28- Perez-Paramo M, Munoz J, Albillos A, Freile I, Portero F, Santos M, et al. Effect of propranolol on the factors promoting bacterial translo-cation in cirrhotic rats with ascites. Hepatology. 2000; 31 (1): 43-48.

29- Shindo M, Ken A, Okuno T. Varying incidence of cirrhosis and hepatocel- 
lular carcinoma in patients with chronic hepatitis $\mathrm{C}$ responding differently to interferon therapy. Cancer. 1999; 85 (9): 1943-1950.

30- Teltschik Z, Wiest R, Beisner J, Nuding S, Hofmann C, SchoelmerichJ, etal. Intestinal bacterial translocation in rats with cirrhosis is related to compromised Paneth cell antimicrobial host defense. Hepatology. 2012; 55 (4): 1154-1163.

31- Yan A, Fouts D, Brandl J, Starkel P, Torralba M, Schott E, et al. Entericdysbiosis associated with a mouse model of alcoholic liver disease. Hepatology. 2011; 53 (1): 96-105.

32-Lichtman S, Sartor R, Keku J, Schwab $\mathrm{J}$. Hepatic inflammation in rats with experimental small intestinal bacterial overgrowth. Gastroenterology. 1990; 98 (2): 414-423.

33-Seki E, De Minicis S, Osterreicher C, Kluwe J, Osawa Y, Brenner D, et al. TLR4 enhances TGF-beta signaling and hepatic fibrosis. Nat Med 2007; 13 (11): 1324-1332.

34- Adachi Y, Bradford B, Gao W, Bojes $\mathrm{H}$, Thurman $\mathrm{R}$. Inactivation of Kupffer cells prevents early alcoholinduced liver injury. Hepatology. 1994; 20 (2):453-460.

35- Kalambokis G, Tsianos E. Rifaximin reduces endotoxemia and improves liver function and disease severity in patients with decompensated cirrhosis. Hepatology. 2012; 55 (2): 655-656.

36- Madrid A, Hurtado C, Venegas $M$, Cumsille F, Defilippi C. Long-Term treatment with cisapride and antibiotics in liver cirrhosis: Effect on small intestinal motility, bacterial overgrowth, and liver function. Am J. Gastroenterol.2001; 96: 1251-1255.

37-Assimakopoulos S, Tsamandas A, Tsiaoussis G, Karatza E, Triantos C, Vagianos C, et al. Altered intestinal tight junctions' expression in patients with liver cirrhosis: A pathogenetic mechanism of intestinal hyperpermeability. EurJClin Invest. 2012; 42 (4): 439-446.
38- Assimakopoulos S. Uncovering the molecular events associated with increased intestinal permeability in liver cirrhosis: the pivotal role of enterocyte tight junctions and future perspectives. J. Hepatol. 2013; 59 (5): 11441146.

39- Genesca J, Marti R, Rojo F, Campos F, Peribanez V, Gonzalez A, et al. Increased tumour necrosis factor alpha production inmesenteric lymph nodes of cirrhotic patients with ascites. Gut. 2003; 52 (7): 1054-1059.

40-Munoz L, Albillos A, Nieto M, Reyes E, Lledo L, Monserrat J, et al. Mesenteric Th1 polarization and monocyte TNF-alphaproduction: First steps to systemic inflammationin rats with cirrhosis. Hepatology. 2005; 42 (2): 411419.

41-Saitoh O, Sugi K, Lojima K, Matsumoto $\mathrm{H}$, Nakagawa K, Kayazawa M, et al. Increased prevalence of intestinal inflammation in patients with liver cirrhosis. World J. Gastroenterol. 1999; 5 (5): 391-396.

42- Lorenzo-Zuniga V, Bartoli R, Planas R, Hofmann A, Vinado B, Hagey L, et al. Oral bile acids reduce bacterial overgrowth, bacterial translocation, and endotoxemia in cirrhotic rats. Hepatology. 2003; 37 (3): 551-557.

43- Du P, Vanheel H, Janssen C, Roos L, Slavik T, Stivaktas P, et al. Activated intestinal macrophages in patients with cirrhosis release NO and IL-6 that may disrupt intestinal barrier function. $\mathbf{J}$. Hepatol. 2013; 58 (6): 1125-1132.

44- Fernández J, Acevedo J, Castro $\mathrm{M}$, Garcia O, de Lope C, Roca D, et al. Prevalence and risk factors of infections by multi resistant bacteria in cirrhosis: A prospective study. Hepatology. 2012; 55 (5): 1551-1561.

45- Gustot T, Durand F, Lebrec D, Vincent J, Moreau R. Severe sepsis incirrhosis. Hepatology. 2009; 50 (6): 2022-2033.

46- Jalan R, Gines P, Olson J, Mookerjee R, Moreau R, Garcia-Tsao G, et al. Acute-on-chronic liver failure. J. Hepatol. 2012; 57 (6): 1336-1348. 
47- Plessier A, Denninger M, Consigny $\mathrm{Y}$, Pessione F, Francoz C, Durand F, et al. Coagulation disorders in patients with cirrhosis and severe sepsis. Liver Int. 2003; 23 (6): 440-448.

48- Moreau R, Jalan R, Gines P, Pavesi M, Angeli P, Cordoba J, et al. Acute-onchronic liver failure is a distinct syndrome that develops in patients with acute decompensation of cirrhosis. Gastroenterology. 2013; 144 (7): 14261437.

49- Merli M, Lucidi C, Giannelli V, Giusto M, Riggio O, Falcone M, et al. Cirrhotic patients are at risk for health care-associated bacterial infections. Clin Gastroenterol Hepatol. 2010; 8 (11): 979-985.

50- Medzhitov R, Schneider D, Soares M. Disease tolerance as a defense strategy. Science. 2012; 335 (6071): 936-941.

51- Tazi K, Bièche I, Paradis V, Guichard $\mathrm{C}$, Laurendeau I, Dargère $\mathrm{D}$, et al. In vivo altered unfolded protein response and apoptosis in livers from lipo poly saccharide-challenged cirrhotic rats. J. Hepatol. 2007; 46: 1075-1088.

52- Navasa M, Follo A, Filella X, Jiménez W, Francitorra A, Planas R, et al. Tumor necrosis factor and interleukin-6 in spontaneous bacterial peritonitis in cirrhosis: Relationship with the development of renal impairment and mortality. Hepatology. 1998; 27 (5): 1227-1232.

53- Terra C, Guevara M, Torre A, Gilabert R, Fernández J, Martín-Llahí M, et al. Renal failure in patients with cirrhosis and sepsis unrelated to spontaneous bacterial peritonitis: value of MELD score. Gastroenterology. 2005; 129 (6): 1944-1953.

54- Trawalé J, Paradis V, Rautou $P$, Francoz C, Escolano S, Sallée M, et al. The spectrum of renal lesions in patients with cirrhosis: A clinico pathological study. Liver Int. 2010; 30 (5): 725-732.

55- Merli M, Lucidi C, Pentassuglio I, Giannelli V, Giusto M, Di Gregorio V, et al. Increased risk of cognitive impairment in cirrhotic patients with bacterial infections. J. Hepatol. 2013; 59 (2): 243-250.

56- Chavarria L, Oria M, Romero-Giménez J, Alonso J, Lope-Piedrafita S, Cordoba $\mathrm{J}$. Brain magnetic resonance in experimental acute-on-chronic liver failure. Liver Int. 2013; 33 (2): 294-300.

57- Bernard B, Grangé J, Khac E, Amiot $\mathrm{X}$, Opolon P, Poynard T. Antibiotic prophylaxis for the prevention of bacterial infections in cirrhotic patients with gastrointestinal bleeding: a metaanalysis. Hepatology. 1999; 29 (6): 1655-1661.

58-Goulis J, Patch D, Burroughs A. Bacterial infection in the pathogenesis of variceal bleeding. Lancet. 1999; 353 (9147): 139-142.

59-Fede G, Spadaro L, Tomaselli T, Privitera G, Germani G, Tsochatzis E, et al. Adrenocortical dysfunction in liver disease: A systematic review. Hepatology. 2012; 55 (4): 1282-1291.

60- Tsai M, Peng Y, Chen Y, Liu N, Ho Y, Fang $\mathrm{J}$, et al. Adrenal insufficiency in patients with cirrhosis, severe sepsis and septic shock. Hepatology. 2006; 43 (4): 673-681.

61- Byl B, Roucloux I, Crusiaux A, Dupont $\mathrm{E}$, Devière $\mathrm{J}$. Tumor necrosis factor alpha and interleukin 6 plasma levels in infected cirrhotic patients. Gastroenterology. 1993; 104(5): 1492-1497.

62- Thevenot T, Borot S, Remy-Martin A, Sapin R, Cervoni J, Richou C, et al. Assessment of adrenal function in cirrhotic patients using concentration of serum-free and salivary cortisol. Liver Int. 2011; 31 (3): 425-433.

63- Thevenot $T$, Dorin R, Monnet $E$, Qualls C, Sapin R, Grandclement E, et al. High serum levels of free cortisol indicate severity of cirrhosis in hemodynamically stable patients. J. Gastroenterol Hepatol. 2012; 27 (10): 1596-1601.

64- Acevedo J, Fernández J, Prado V, Silva A, Castro M, Pavesi M, et al. Relative adrenal insufficiency in dec- 
ompensated cirrhosis: Relationship to short- term risk of severe sepsis, hepatorenal syndrome, and death. Hepatology. 2013; 58 (5): 17571765.

65- De Mattos A, Costabeber A, Lionço L, Tovo C. Multi-resistant bacteria in spontaneous bacterial peritonitis: A new step in management? .World J. Gastroenterol. 2014; 20 (39): 14079-14086.

66- Fernández J, Navasa $M$, Gómez J, Colmenero J, Vila J, Arroyo V, et al. Bacterial infections in cirrhosis: Epidemiological changes with invasive procedures and norfloxacin prophylaxis. Hepatology. 2002; 35 (1): 140-148.

67- Ginès $\mathrm{P}$, Angeli $\mathrm{P}$, Lenz $\mathrm{K}$, et al. EASL clinical practice guidelines on the management of ascites, spontaneous bacterial peritonitis, and hepatorenal syndrome in cirrhosis. J. Hepatol. 2010; 53 (3): 397 417.

68-Merli M, Lucidi C, Giannelli V, Giusto M, Riggio O, Falcone M, et al. Cirrhotic patients are at risk for health care-associated bacterial infections. Clin Gastroenterol Hepatol. 2010; 8 (11): 979-985.

69- Singh N, Wagener M, Gayowski T. Changing epidemiology and predictors of mortality in patients with spontaneous bacterial peritonitis at a liver transplant unit. Clin Microbiol Infect. 2003; 9 (6): 531-537.

70-Peck K, Cheong H, Kang C-I, Lee J, Moon S, Joung $M$, et al. Clinical significance and outcome of nosocomial acquisition of spontaneous bacterial peritonitis in patients with liver cirrhosis. Clin Infect Dis. 2009; 48(9): 1230-1236.

71-Bajaj J, O’Leary J, Reddy K, Wong F, Biggins S, Patton H, et al. Survival in infection-related acute-on-chronic liver failure is defined by extrahepatic organ failures. Hepatology. 2014; 60 (1): 250-256.

72-Lim K, Potts J, Chetwood J, Goubet S, Verma S. Long-term outcomes after hospitalization with spontaneous bacterial peritonitis. J. Dig Dis. 2015; 16 (4): 228240.
73- Titó L, Rimola A, Ginès $\mathrm{P}$, Llach J, Arroyo V, Rodés J. Recurrence of spontaneous bacterial peritonitis in cirrhosis: Frequency and predictive factors. Hepatology. 1988; 8 (1): 27-31.

74- Follo A, Llovet J, Navasa M, Planas R, Forns X, Francitorra A, et al. Renal impairment after spontaneous bacterial peritonitis in cirrhosis: Incidence, clinical course, predictive factors and prognosis. Hepatology. 1994; 20 (6): 1495-1501.

75-Tandon P, Garcia-Tsao G. Bacterial infections, sepsis, and multi organ failure in cirrhosis. Semin Liver Dis. 2008; 28 (1): 26-42.

76-Runyon B, Canawati H, Akriviadis E. Optimization of ascitic fluid culture technique. Gastroenterology. 1988; 95 (5): 1351-1355.

77- Wilcox C, Dismukes W. Spontaneous bacterial peritonitis. A review of pathogenesis, diagnosis, and treatment. Medicine (Baltimore). 1987; 66 (6): 447-456.

78- Jalan R, Fernandez J, Wiest R, Schnabl $\mathrm{B}$, Moreau R, Angeli $\mathrm{P}$, et al. Bacterial infections in cirrhosis: A position statement based on the EASL Special Conf. 2013. J. Hepatol. 2014; 60 (6): 13101324.

79- Fernández J, Acevedo $\mathrm{J}$, Castro $\mathrm{M}$, Garcia O, de Lope C, Roca D, et al. Prevalence and risk factors of infections by multi resistant bacteria in cirrhosis: A prospective study. Hepatology. 2012; 55 (5): 1551-1561.

80- Rimola A, Garcia-Tsao G, Navasa M, Piddock L, Planas R, Bernard B, et al. Diagnosis, treatment and prophylaxis of spontaneous bacterial peritonitis: A consensus document. International Ascites Club. J. Hepatol. 2000; 32 (1): 142-153.

81-Evans L, Kim W, Poterucha J, Kamath P. Spontaneous bacterial peritonitis in asymptomatic outpatients with cirrhotic ascites. Hepatology. 2003; 37 (4): 897-901.

82- Van de Geijn G, van Gent M, van PulBom N, Beunis M, van Tilburg A, Njo T. A new flow cytometric method for differential cell counting in ascitic fluid. Cytometry B Clin Cytom. 2016; 90 (6): 506-511. 
83- Fleming C, Brouwer R, van Alphen A, Lindemans J, de Jonge R. UF-1000i: validation of the body fluid mode for counting cells in body fluids. Clin Chem Lab Med. 2014; 52 (12): 1781-1790.

84- Gravito-Soares M, Gravito-Soares E, Lopes S, Ribeiro G, Figueiredo P. Spontaneous fungal peritonitis: A rare but severe complication of liver cirrhosis. Eur J. Gastroenterol Hepatol. 2017; 29 (9): 1010-1016.

85- Sort P, Navasa M, Arroyo V, Aldeguer $\mathrm{X}$, Planas R, Ruiz-del-Arbol L, et al. Effect of intravenous albumin on renal impairment and mortality in patients with cirrhosis and spontaneous bacterial peritonitis. N Engl J Med. 1999; 341 (6): 403-409.

86- Wiest R, Krag A, Gerbes A. Spontaneous bacterial peritonitis: Recent guidelines and beyond. Gut. 2012; 61 (2): 297-310.

87- Fernandez J, Tandon P, Mensa J, GarciaTsao G. Antibiotic prophylaxis in cirrhosis: Good and bad. Hepatology. 2016; 63 (6): 2019-2031.

88- Fasolato S, Angeli P, Dallagnese L, et al. Renal failure and bacterial infections in patients with cirrhosis: Epidemiology and clinical features. Hepatology 2007; 45: 223-229.

89- Fernandez J, Acevedo J, Arroyo V. Response to the clinical course and shortterm mortality of cirrhotic patients with non-spontaneous bacterial peritonitis infections. Liver Int. 2017; 37 (3): 623.

90-Bernardi M, Ricci C, Zaccherini G. Role of human albumin in the manage-ment of complications of liver Cirrhosis. J. Clin. Exp. Hepatol. 2014; 4 (4): 302-311.

91- Moreau R, Jalan R, Gines P, Pavesi M, Angeli P, Cordoba J, et al. Acute-onchronic liver failure is a distinct syndrome that develops in patients with $\mathrm{AD}$ of cirrhosis. Gastroenterology. 2013; 144 (7): 1426-1437.

92- Jalan R, Fernandez J, Wiest R, Schnabl B, Moreau R, Angeli P, et al. Bacterial infections in cirrhosis: A position statement based on the EASL Special Conf. J. Hepatol. 2013; 60 (6): 1310-1324.

93- Fernandez J, Acevedo J, Castro M, Garcia O, de Lope C, Roca D, et al. Prevalence and risk factors of infections by multi resistant bacteria in cirrhosis: a prospective study. Hepatology. 2012; 55 (5): 1551-1561.

94- Piano S, Brocca A, Mareso S, Angeli P. Infections complicating cirrhosis. Liver Int. 2018; 38 (1): 126-133.

95- Bartoletti M, Giannella M, Lewis R, Caraceni P, Tedeschi S, Paul M, et al. A prospective multicentre study of the epidemiology and outcomes of bloodstream infection in cirrhotic patients. Clin Microbiol Infect. 2018; 24 (5): 546-554. 